\title{
INDUSTRIALISASI PERTAMBANGAN DAN DEAGRARIANISASI MASYARAKAT DESA \\ (Studi Kasus Masyarakat Desa Embalut dan Desa Bangunrejo, Kecamatan Tenggarong Seberang, Kabupaten Kutai Kartanegara, Kalimantan Timur)
}

\section{Mining Industrialization and Deagrarianization in Rural Community (A case Study of Community Embalut and Bangunrejo, Tenggarong Seberang District, Kutai Kartanegara Regency, East Kalimantan)}

\author{
Rajib Gandi*), Satyawan Sunito, dan Rilus A. Kinseng \\ Program Studi Sosiologi Pedesaan, Fakultas Ekologi Manusia, Institut Pertanian Bogor \\ *Email: rajibgandi06@gmail.com
}

\begin{abstract}
East Kalimantan province has issued a mining license (IUP) reached 1,192 pieces, until August 2014. Kutai Kartanegara is a county that issued the largest IUP is 407 companies, which 218 companies have been involved in the production, while the remaining 189 are still in the exploratory stage. Embalut village and village Bangunrejo which become part of the administration Tenggarong Seberang Sub-District, Kutai Kartanegara, is a village that has more than 30 years was associated with the mining industry, PT. Kitadin. The results showed that: (1) the mining industrialization has changed the structure of land in the village Embalut and village Bangunrejo where land holdings in both villages have concentrated on coal mining companies. (2) mining Industrialization increasingly encourage people to work or livelihood in outside agriculture (deagrarianization). This study used qualitative methods, with in-depth interview techniques, group discussions, observation, and study of literature / documents.
\end{abstract}

Keywords: deagrarianization, industrialization mining, land tenure

\begin{abstract}
ABSTRAK
Provinsi Kalimantan Timur telah mengeluarkan izin usaha pertambangan (IUP) mencapai 1.192 buah, sampai Agustus 2014. Kutai Kartanegara adalah daerah yang menerbitkan IUP terbesar adalah 407 perusahaan, yang 218 perusahaan telah terlibat dalam produksi, sedangkan sisanya 189 masih dalam tahap eksplorasi. Desa Embalut dan desa Bangunrejo yang menjadi bagian dari pemerintahan Tenggarong Seberang Kecamatan, Kutai Kartanegara, adalah sebuah desa yang memiliki lebih dari 30 tahun dikaitkan dengan industri pertambangan, PT. Kitadin. Hasil penelitian menunjukkan bahwa: (1) industrialisasi pertambangan telah mengubah struktur tanah di desa Embalut dan desa Bangunrejo mana kepemilikan lahan di kedua desa telah berkonsentrasi pada perusahaan pertambangan batubara. (2) pertambangan Industrialisasi semakin mendorong orang untuk bekerja atau mata pencaharian di luar pertanian (deagrarianisasi). Penelitian ini menggunakan metode kualitatif, dengan teknik wawancara mendalam, diskusi kelompok, observasi, dan studi literatur / dokumen.
\end{abstract}

Kata kunci: deagrarianisasi, idustrialisasi pertambangan, kepemilikan lahan.

\section{PENDAHULUAN}

\section{Latar Belakang}

Kegiatan tambang sebenarnya bukan merupakan hal baru di Indonesia. Di daerah-daerah, kegiatan tambang telah berlangsung sejak jaman kerajaan. Menurut catatan Erwiza (2007), jika di Bangka menunjukkan bahwa industri tambang, bahkan beserta ekonomi illegalnya (penambangan liar), bukanlah sebuah fenomena baru, tetapi sudah berlangsung sejak ekonomi politik di abad ke-18 sampai abad ke-21, melintasi rezim yang berbeda dari pra-kolonial, kolonial, pasca-kolonial sampai zaman pasca reformasi ini. Salah satu daerah di Indonesia yang memiliki frekuensi kegiatan tambang tinggi, sekaligus sebagai 'motor' utama ekonomi daerahnya adalah Provinsi Kalimantan Timur dan Kabupaten Kutai Kartanegara. Hingga Agustus 2014 tercatat Ijin Usaha Pertambangan (IUP) yang telah diterbitkan oleh Pemerintah Daerah Provinsi Kalimantan Timur mencapai
1192 buah. Kabupaten Kutai Kartanegara adalah daerah yang tercatat terbanyak mengeluarkan IUP yaitu sebanyak 407 perusahaan, dimana 218 perusahaan telah melakukan kegiatan produksi, sedangkan sisanya 189 masih berada pada tahap eksplorasi.

Salah satu kecamatan di Kabupaten Kutai Kartanegara dengan aktivitas tambangnya yang masif adalah Kecamatan Tenggarong Seberang. Kecamatan Tenggarong Seberang memiliki luas wilayah mencapai $464,25 \mathrm{~km} 2$ dengan jumlah penduduk mencapai 65.014 jiwa tahun 2010 yang tersebar di 18 desa (BPS Kutai Kartanegara, 2013). Saat ini terdapat 17 perusahaan tambang yang telah mengantongi IUP operasi produksi dan 7 perusahaan yang berstatus IUP eksplorasi. Hanya dengan 17 perusahaan tambang yang telah beroperasi produksi itu ternyata telah menguasai lahan seluas $21.862,15$ ha, atau setara dengan 47,1 persen dari total luas Kecamatan Tenggarong Seberang. 
Kehadiran perusahaan tambang dalam jumlah yang cukup besar sangat berpengaruh terhadap keadaan sosial, ekonomi dan ekologi di sana. Bahkan dalam sebuah laporan jurnalistik nasional belum lama ini, dilaporkan bahwa 10 kecamatan di Kutai Kartanegara terancam bencana karena praktik tambang yang merajalela (Kompas.com, 2013). Dari kesepuluh kecamatan yang terancam bencana, termasuk di dalamnya adalah Kecamatan Tenggarong Seberang. Tidak dipungkiri, jika kehadiran perusahaan-perusahaan tambang tersebut telah melebihi daya tampung alamnya, sehingga menjadi sumber bencana di Tenggarong Seberang.

Dua desa yang menjadi bagian administrasi Kecamatan Tengarong Seberang, yaitu Desa Embalut dan Bangunrejo adalah desa yang sudah lebih dari 30 tahun ini berhubungan dengan industri tambang, khususnya dengan perusahaan tambang PT. Kitadin. Saat ini perusahaan-perusahaan tambang menguasai sebagian besar lahan di Desa Embalut dan Bangunrejo. Terhitung terdapat total enam perusahaan tambang yang berada di kedua desa itu yaitu PT. Kitadin , PT. Gerbang Daya Mandiri, PT. Bukit Baiduri Energi, PT. Kalimantan Persada Coal, PT. La Tahzan, dan PT. Kaltim Bio Energi. Ke enam perusahaan tambang tersebut telah mengantongi izin lokasi untuk penguasaan lahan dengan total luas 14.582 ha, jauh melebihi luas Desa Embalut dan Desa Bangunrejo yang hanya bertotal 5.500 ha. Memang, penguasaan lahan enam perusahaan tambang tersebut juga meliputi beberapa desa lainnya yang ada di sekitar Desa Embalut dan Bangunrejo. Akan tetapi, dengan penguasaan lahan yang begitu besar tersebut membuat perusahaan tambang tetap menjadi penguasa lahan yang begitu dominan.

Padahal sebelum kehadiran perusahaan-perusahaan tambang, penguasaan lahan sebagian besar diperuntukan bagi pertanian yang dikelola oleh masyarakat. Desa Embalut yang dihuni oleh Suku Kutai, lebih memanfaatkan lahan untuk pertanian berladang. Adapun masyarakat Desa Bangunrejo yang merupakan masyarakat transmigran yang dibekali oleh pemerintah 2 ha tanah, dengan pembagian lahan untuk lahan tani sawah 1 ha, 0,75 ha untuk tanah ladang dan sisanya 0,25 ha untuk rumah dan pekarangan.

Kehadiran industri pertambangan pasti menimbulkan dampak bagi masyarakat yang berada di dekatnya. Industri yang ditempatkan di desa dan memperkejakan banyak warga desa sebagai buruh industri menurut status kerja, waktu kerja dan tingkat upah kerja tertentu, maka pola hubungan keluarga serta ketetanggaan berubah sesuai status dan waktu kerja buruh industri yang menjadi warga desa tersebut, diferensiasi institusi ekonomi desa meningkat, serta pola produksi pertanian berubah lebih komersial (Agusta, 1997). Maka tak heran, perubahan penguasaan tanah yang terpusat dibeberapa pihak, sistem nafkah yang semakin komersial dan cenderung eksploitatif, pembangunan infrastruktur meningkat, serta kelembagaan sosial dalam kerangka pengaturan hubungan-hubungan baru adalah gejala umum yang terjadi dalam praktek industri tambang.

Masyarakat setempat memang memperoleh beberapa manfaat yang diciptakan oleh pertambangan, terutama terkait dengan mata pencaharian dengan upah lebih tinggi dan tetap (O'Faircheallaigh, 2012). Namun di sisi lain, industri tambang juga menimbulkan masalah sosial berupa kesehatan dan gizi buruk, perang, bencana alam, kelaparan, pertumbuhan penduduk dan tekanan pada sumber daya, degradasi lingkungan, dampak yang tidak 'pantas' dari teknologi padat modal dan kegagalan pelayanan pemerintah untuk menyediakan kebutuhan dasar (Redclift, 1984).

Ragam dampak dari industrialisasi pertambangan di suatu daerah menjadi sebuah keniscayaan. Berangkat dari hal tersebut penelitian ini berupaya untuk menjawab dari pertanyaan penelitian, seperti apa industrialisasi pertambangan yang mendorong perkembangan desa, serta konsekuensinya terhadap pola nafkah pertanian masyarakat desa?. Pertanyaan penelitian tersebut lalu dirumuskan dalam dua rumusan pertanyaan yang lebih spesifik yaitu:

1. Seperti apa proses berkembangnya industrialisasi pertambangan di desa?

2. Sejauhmana industrialisasi pertambangan memiliki konsekuensi terhadap perubahan struktur agraria dan sistem nafkah masyarakat desa?

\section{METODE PENELITIAN}

Penelitian ini dilaksanakan di Desa Bangunrejo dan Embalut, Kecamatan Tenggarong Seberang, Kabupaten Kutai Kartanegara, Provinsi Kalimantan Timur. Lokasi penelitian dipilih secara sengaja, karena mempertimbangkan aktivitas pertambangan yang sangat tinggi di kedua desa tersebut. Waktu penelitian ini sendiri dilaksanakan pada Bulan Juli sampai Agustus Tahun 2014. Penelitian ini menggunakan berbagai jenis data yang dikelompokan menjadi data sekunder dan data primer. Untuk pendekatan kualitatif penentuan informan dilakukan secara purposive dan melalui teknik bola salju. Lebih khusus, informan yang dipilih disesuaikan dengan pertanyaan penelitian, dan informasi awal yang diperoleh. Teknik yang digunakan dalam penelitian ini adalah wawancara mendalam, diskusi kelompok, observasi, dan studi literature/dokumen.

\section{HASIL}

Industri tambang merupakan transfer energi/bahan, sebuah aliran 'bersih' dari materi, energi, nilai lingkungan dan manusia, dari daerah pinggiran untuk pusat, dimana ada nilai yang ditambahkan (O'Faircheallaigh, 2012). Pertambangan biasanya membawa serta perkembangan pesat dan perubahan yang signifikan, seperti lapangan kerja, arus besar modal dan dalam beberapa kasus membuat migrasi dan pemukiman baru (Kemp, 2009). Untuk proses tumbuh kembang industi tambang, dimulai dari tahap pra kontruksi, kontruksi, operasi sampai pasca operasi.

Di daerah Kabupeten Kutai Kartanegara perijinan pertambangan telah diatur melalui Peraturan Daerah Kabupaten Kutai Kartanegara Nomor 2 Tahun 2013 Tentang Pengelolaan Pertambangan Mineral dan Batubara. Dalam peraturan daerah tersebut, pemerintah daerah diharuskan membuat terlebih dahulu perencanaan dan penetapan Wilayah Pertambangan (WP) yang disesuaikan dengan Rencana Tata Ruang Wilayah (RTRW). WP ini kemudian dilengkapi dengan ketersediaan data, potensi dan/atau informasi geologi yang kemudian disebut sebagai Wilayah Usaha Pertambangan(WUP). WUP ditetapkan oleh Menteri Energi dan Sumber Daya Mineral (ESDM) yang dapat ditinjau kembali 1 (satu) kali dalam lima tahun. Beranjak dari WUP inilah pemerintah daerah menetapkan wilayahwilayah mana yang akan diberikan kepada pemegang 
Ijin Usaha Pertambangan (IUP) yang akhirnya ditetapkan sebagai Wilayah Izin Usaha Pertambangan (WIUP).

Meskipun persyaratannya untuk dapat memperoleh IUP cukup panjang. Apalagi kehadiran tambang harus memperhatikan berbagai aspek karena berkaitan dengan ekosistem dan makhluk hidup di dalamnya seperti aspek sosial, budaya, ekonomi dan lingkungan. Sehingga, pengontrolan IUP yang lemah hanya akan menciptakan masalah yang lebih besar. Nyatanya, pertambangan tetap mendapatkan tempat yang 'layak'. Hingga Agustus 2014 tercatat IUP yang telah diterbitkan oleh Pemerintah Daerah Provinsi Kalimantan Timur mencapai 1192. Kabupaten Kutai Kartanegara adalah daerah yang tercatat terbanyak mengeluarkan IUP yaitu sebanyak 407 perusahaan, dimana 218 perusahaan telah melakukan kegiatan produksi, sedangkan sisanya 189 masih berada pada tahap eksplorasi.

Pemberian ijin yang dilakukan selama ini lebih mengarah pada pemberian ijin (ploting ijin) yang tidak memperhatikan rencana pemanfaatan lahan yang telah dibuat. Pendekatan yang selama ini dilakukan, tidak masalah sebanyak-banyaknya ijin yang diberikan, karena dari proses pemberian ijin itu nantinya akan masuk pada tahap eksplorasi yang baru berlanjut kepada tahap eksploitasi, artinya ijin-ijin yang diberikan itu belum tentu ditambang (Kinseng et all, 2013). Di Kabupaten Kutai Kartanegara terdapat dua lokasi utama yang direncanakan sebagai daerah tambang yang terletak di dominan bagian ilir Sungai Mahakan, dan sebagian kecil di wilayah bagian tengah kabupaten. Sisa wilayah tersebut direncanakan menjadi daerah perkebunan (Kinseng et all, 2013).

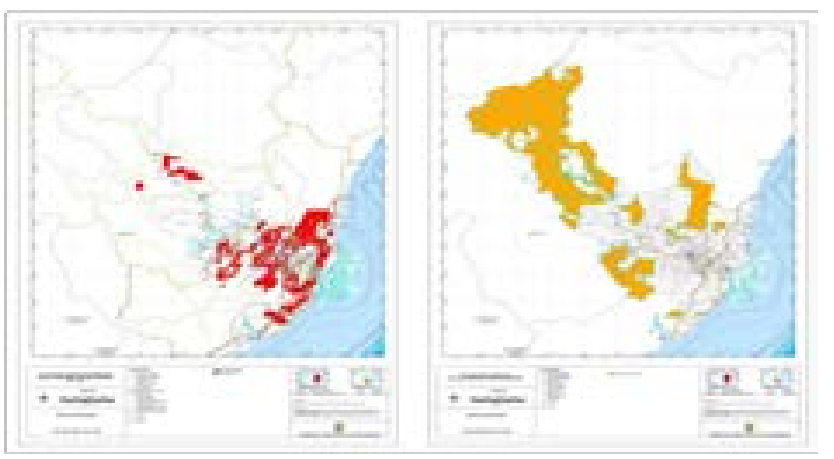

Gambar 1. Peta Perencanaan Kawasan Pertambangan Batubara (kiri) dan Kawasan Perkebunan (kanan) di Kabupaten Kutai Kartanegara (2011-2031)

Di Desa Embalut dan Bangunrejo, Kecamatan Tenggarong Seberang industri tambang telah hadir sejak tiga puluh tahun lalu, yaitu dengan masuknya PT. Kitadin. PT. Kitadin telah melakukan eksplorasi dari tahun 1980, meskipun banyak masyarakat yang lebih mengetahuinya baru di tahun 1983. Surat ijin eksplorasinya dikeluarkan oleh Direktorat Jenderal Pertambangan Umum, pada tanggal 28 Mei 1980, dengan nomor surat keputusan 1562/K-DJ/213/ DUP Tahun 1980. Ijin-ijin pertambangan di waktu itu masih harus dilakukan ke pemerintah pusat di Jakarta. Sekedar perluasan eksploitasi tambang pun harus di sampaikan ke Jakarta. Proses ini berlangsung cukup lama, hingga dua dekade lebih. Baru semenjak reformasi dan adanya dorongan kuat untuk otonomi daerah, di tahun 2003 ijin perpanjangan KP eksploitasi PT. Kitadin di keluarkan oleh Pemerintah Daerah Kabupaten Kutai Kartanegara. Kewenangan pemerintah daerah untuk mengatur perusahaan pertambangan yang memiliki ijin Kuasa Pertambangan (KP) semakin menguat setelah diberlakukannya otonomi daerah dengan pengukuhan Undang-Undang Nomor 32 Tahun 2004 tentang Pemerintah Daerah dan Undang-Undang Nomor 34 Tahun 2004 tentang Perimbangan Keuangan antara Pusat dan Daerah. Kehadiran kedua undang-undang desentralisasi tersebut dengan serta merta membawa pengaruh besar dalam mengubah kegiatan pembangunan dan peningkatan ekonomi di daerah, termasuk perkembangan industri tambang.

Hingga saat ini lahan yang telah digunakan PT. Kitadin untuk kegiatan tambang mencapai 1.468,07 Ha. Namun, untuk terus meningkatkan produksi batubara, PT. Kitadin berupaya menambah luas lahan sebesar 597,63 Ha. Jadi, total luasan lahan yang telah dan akan digunakan PT. Kitadin mencapai 2.065,70 Ha. Lahan-lahan yang akan digunakan sebagian besar telah dilakukan pembebasan lahan oleh pihak perusahaan. Kegiatan pembebasan lahan dilakukan dengan ganti rugi atas tanah dan tanam tumbuh pada lahan masyarakat yang terkena kegiatan penambangan sesuai Surat Keputusan Bupati Kutai Kartanegara No.180.188/ HK- 630/2008 tanggal 08 Juli 2008. Dalam prakteknya, pembebasan lahan dilakukan dengan dua tipe, yaitu pinjam pakai dengan masyarakat dan ada yang ganti putus. Tipe ke dua, ganti putus menjadi mekanisme yang paling umum digunakan.

Seiring dengan berjalannya waktu kebutuhan atas tanah semakin tinggi, apalagi perusahaan yang terus meningkatkan produksinya. Maka tidak dipungkiri harga tanah pun turut meningkat. Paradigma dimasyarakat saat ini telah berubah, tanah bukan lagi sebagai faktor produksi tapi telah menjadi objek investasi yang bernilai tinggi. Tak heran akhirnya muncul para spekulan-spekulan yang menjadi makelar tanah demi memperoleh keuntungan atas harga tanah yang semaki tinggi tersebut.

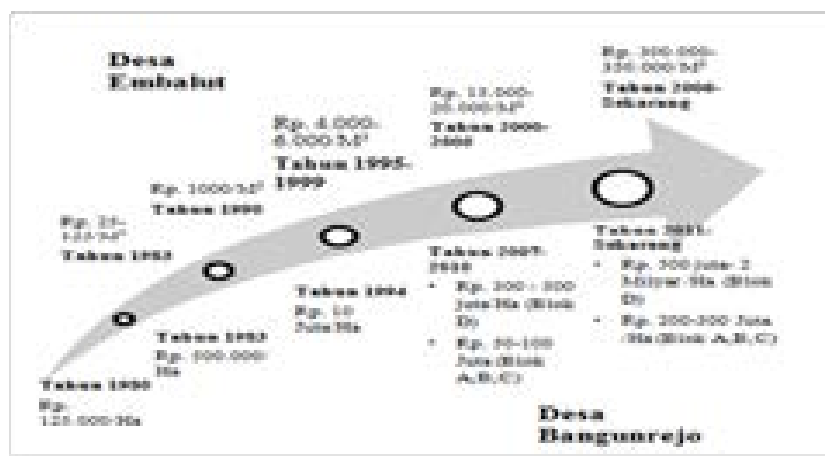

Sumber:Data Primer, 2014 dan Kinseng et all, 2013 (diolah)

Gambar 2. Dinamika Harga Tanah Di Desa Embalut dan Desa Bangunrejo dari Tahun ke Tahun

"Kalo tanah tidak berharga, gak ada peduli. Tapi sekarang setelah ada tanah yang berharga $1 M, 2 M$ per hektar itu yang menjadi pemicu (tanah menjadi objek investasi)." (MAJ, PNS)

Untuk produksi penambangan yang mencapai 1,5 juta ton di tahun 2012 PT.Kitadin menggunakan tenaga kerja yang berjumlah secara keseluruhan sebesar 1.478 orang tenaga kerja. Dari 1.478 orang tenaga kerja tersebut, hanya 168 orang yang merupakan tenaga kerja tetap, sisanya adalah termasuk tenaga kerja tidak tetap. Sistem kerja yang 
dijalankan oleh PT. Kitadin menggunakan sistem kontrak penambangan batubara, sehingga tenaga kerja yang bekerja pada proyek penambangan terbagi menjadi dua yaitu:

\section{a. Tenaga Kerja Tetap.}

Tenaga kerja yang diangkat sebagai karyawan tetap perusahaan berdasarkan perjanjian kerja yang disepakati bersama. Tenaga kerja tetap ini nantinya mengisi formasi yang ada dalam struktur organisasi PT.Kitadin.

\section{b. Tenaga Kerja Tidak Tetap}

Tenaga kerja ini biasanya berasal dari perusahaan kontraktor yang men-sub ke perusahaan induk (PT.Kitadin). Tenaga kerja yang bekerja pada kontraktor berjumlah sekitar 800 orang, namun jika produksi sedang pada puncaknya tenaga kerja ini bisa meningkat menjadi 1.300 orang.

Saat ini, penggunaan alat-alat canggih sudah lebih dominan digunakan pada tambang luar dibanding saat tambang dalam. Hal ini berimplikasi pada spesifikasi tenaga kerja yang dibutuhkan. Pendidikan minimum Sekolah Menengah Atas (SMA) sudah menjadi hal lumrah dalam perekrutan kerja tambang, baik untuk tenga kerja terampil maupun tidak terampil. Tambang luar terbuka ini lebih menekankan pada penggunaan teknologi dan alat berat dalam mengeruk batubara, tidak seperti tambang dalam yang lebih menggunakan tenaga manusia. Konsekuensinya adalah tenaga kerja berpendidikan tinggi yang diperlukan, karena dianggap lebih mampu adaptif dengan sistem baru ini. Akan tetapi, kontradiksi terjadi dimana ternyata dari data Profil Desa Embalut 2012 menunjukkan jika 55\% lebih (1.229 jiwa) penduduk Desa Embalut hanya berpendidikan tamatan Sekolah Dasar. Realitas ini tentu membuat sebagian besar masyarakat Embalut kesulitan untuk mampu bersaing bekerja dalam industri pertambangan yang hadir saat ini.

\section{Tabel 1. Tenaga Kerja PT. Kitadin Tahun 2012}

\begin{tabular}{lllll}
\hline No & Klasifikasi & Indonesia & Asing & $\begin{array}{l}\text { Jum- } \\
\text { lah }\end{array}$ \\
\hline 1 & Direktur & 1 & 1 & 2 \\
2 & Manager/Profesional & 2 & 1 & 3 \\
3 & Supervisor/Technical & 66 & 2 & 68 \\
4 & Tenaga Terampil & 26 & 0 & 26 \\
5 & Tenaga Administrasi & 6 & 0 & 6 \\
6 & Tenaga Tidak Ter- & 63 & 0 & 63 \\
Total & ampil & 164 & 4 & 168 \\
\hline
\end{tabular}

\section{Sumber: Andal PT.Kitadin 2013}

Tahapan operasi menitikberatkan pada tahapan dimana perusahaan sudah memulai produksi untuk mengeluarkan batubara menjadi hasil tambang, yang kemudian mengangkut hasil tambang ke titik pengumpulan dan kemudian baru mengirimkan hasil tambang tersebut. PT. Kitadin mempunyai sumberdaya yang cukup untuk dikembangkan. Berdasarkan studi internal PT. Kitadin yang dilakukan pada tahun 2000 , target produksi PT. Kitadin sebelumnya 1,1 juta ton/tahun yang akan berakhir pada tahun 2015. Namun pada tahun 2004 dari hasil eksplorasi lanjutan ternyata diketemukan tambahan cadangan batubara sebesar 4,15 juta ton. Dari itu, pada akhir tahun 2012, PT. Kitadin diketahui mempunyai cadangan batubara untuk tambang terbuka sebesar 9,2 juta ton, yang kemudian dalam studi kelayakan sebelumnya menjadi direvisi dan dibuat studi kelayakan baru dengan target produksi puncak 1,5 juta ton/tahun dan penambangan akan berakhir tahun 2019. Adapun produksi batubara tambang terbuka yang telah dihasilkan dari tahun 2009 sampai 2012 sebesar 14,76 juta ton (14.760.171 ton).

Saat ini di lahan PT.Kitadin eksplorasi tambang batubara secara aktif masih terus berlangsung, namun di sisi lain juga nampak daerah-daerah yang sudah direklamasi dan dikembangkan. Peraturan Menteri Energi dan Sumber Daya Mineral RI Nomor 18 Tahun 2008 Tentang Reklamasi dan Penutupan Tambang, yang kemudian diperkuat dengan Peraturan Pemerintah RI No.78 Tahun 2010 Tentang Reklamasi dan Pasca Tambang dikeluarkan untuk menjamin agar pemanfaatan lahan di wilayah bekas kegiatan tambang pertambangan agar berfungsi sesuai peruntukannya dengan prinsip-prinsip lingkungan hidupnya, keselamatan dan kesehatan kerja, serta konservasi bahan galian.

Daerah yang sudah direklamasi banyak sekali ditanami dengan tanaman-tanaman hutan, seperti trembesi, sengon dan lamtoro. Dengan dominannya tanaman-tanaman tersebut, memperlihatkan bagaimana corak reklamasi yang dilakukan hanya menekankan pada aspek fisik lingkungan. Padahal dengan kontur tanah yang relatif datar sangat cocok untuk pemanfaatan pertanian, peternakan dan pemukiman. Di Desa Embalut pemanfaatan lahan bekas tambang ada yang sudah dijadikan sebagai Kebun Pertanian Terpadu yang kurang lebih luasnya mencapai $15 \mathrm{Ha}$. Kebun ini dikelola oleh kelompok tani yang mencoba memanfaatkan tanah baik yang berasal dari topsoil atau bukan tanah pucuk bekas tambang. Pada pertanian terpadu ini tidak hanya untuk pertanian saja seperti menanam jagung, singkong gajah, dan tanaman palawija lainnya, akan tetapi dibudidayakan juga perikanan, diantaranya ikan lele, mas, dan nila, serta dikembangkan peternakan yaitu diantaranya sapi dan ayam.

Jika di Desa Bangunrejo sudah ada kolam ex galian batubara yang dimanfaatkan oleh masyarakat sebagai budi daya ikan keramba. Kedepannya, menurut penuturan dari pihak desa, jika kolam-kolam besar dari bekas galian tambang itu diserahkan ke desa, maka akan dimanfaatkan tidak hanya untuk perikanan, budi daya ikan, namun juga akan didorong untuk objek wisata. Dengan adanya aktivitas pariwisata ini diharapkan akan membangkitkan sektor ekonomi desa secara keseluruhan.

Lahan yang ada saat ini memang masih dalam konsesi PT. Kitadin, namun inisiasi untuk mengembangkan daerahdaerah bekas tambang sudah terbangun dari kedua desa. Mempertimbangkan rencana dan apa yang sudah dilakukan terhadap lahan bekas tambang, maka memang jika kita melihat bahwa aturan pasca pertambangan menempatkan fungsi lingkungan lebih besar, hal tersebut tentu dirasa tidak tepat. Di ke dua desa, penggunaan lahan untuk pengembangan pertanian, perikanan, dan peternakan sudah menunjukkan tanda-tanda keberhasilannya, walaupun belum berhasil mencakup masyarakat secara lebih luas.

Pada pemerintah Desa Embalut, bahkan perencanaan ke depan sudah disusun, dan arah perumahan dan perencanaan 
penggunaan sudah dirancang dengan lebih nyata yaitu melalui peta master plan desa. Bentuk inisiasi seperti ini sangat diperlukan dalam pemanfaatan daerah pasca tambang. Dengan begitu, potensi pengembangan dapat diarahkan ke berbagai pilihan yang sudah disesuaikan dengan kebutuhan dari masyarakat. Meskipun begitu, master plan yang ada harus tetap memperhatikan konteks lingkungan dan beragam perubahan yang terjadi di masyarakat. Selain itu, pada proses perancangan pun semestinya dengan melibatkan partisipasi dari masyarakat. Maka melalui master plan ini, maka alokasi ruang untuk faktor produksi dan juga untuk penduduk dapat diatur lebih baik, seperti halnya yang sudah dikembangkan dalam konsep pertanian terpadu (Kinseng et all, 2013).

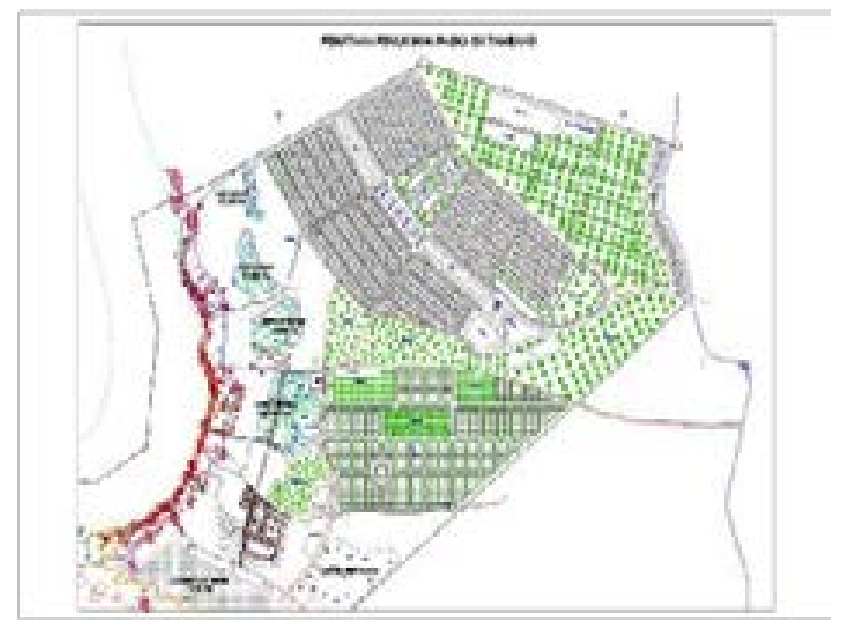

Gambar 3. Peta Master Plan Desa Embalut, Tahun 2012

\section{PERUBAHAN STRUKTUR AGRARIA}

\section{Perubahan Struktur Agraria di Kabupaten Kutai Kartanegara dan Kecamatan Tenggarong Seberang}

Pada Sensus Pertanian 2013 diketahui jika jumlah usaha pertanian di Kabupaten Kutai Kartanegara sebanyak 56.093 dikelola oleh rumah tangga, 122 dikelola oleh perusahaan pertanian berbadan hukum dan 5 dikelola oleh selain rumah tangga dan perusahaan berbadan hukum. Dari 18 Kecamatan di Kabupaten Kutai Kartanegara, Kecamatan Samboja memiliki jumlah rumah tangga pertanian terbesar yaitu mencapai 5.749 rumah tangga, kemudian disusul oleh Kecamatan Tenggarong Seberang dengan jumlah 5.289 rumah tangga petani.

Dalam Sensus Pertanian 2013 diketahui pula jika ternyata telah terjadi penurunan jumlah rumah tangga usaha pertanian di Kabupaten Kutai Kartanegara sebanyak 4.415 rumah tangga dari 60.508 rumah tangga pada tahun 2003 menjadi 56.093 rumah tangga pada tahun 2013. Berarti telah terjadi penurunan rumah tangga petani di Kabupaten Kutai Kartanegara sebesar 7,30 persen. Walaupun Kecamatan Tenggarong Seberang adalah termasuk daerah yang memiliki jumlah rumah tangga petani tertinggi, namun nyatanya mengalami angka penurunan yang tertinggi pula yaitu sebesar 2.139 rumah tangga atau $-28,80$ persen. Penurunan tertinggi kedua disusul oleh Kecamatan Loa Janan sebanyak 2.043 rumah tangga atau $-37,56$ persen. Hal berbeda dialami oleh Kecamatan Muara Badak yang mengalami kenaikan yaitu sebanyak 1.307 rumah tangga (53,02 persen).
Kecamatan Tenggarong Seberan adalah centra pertanian, khususnya pertanian padi sawah, di Kabupaten Kutai Kartanegara. Hal ini ditunjukan secara luas tanam, luas panen, produktivitas maupun produksi pertaniannya yang tertinggi se Kabupaten Kutai Kartanegara. Di Tahun 2012, luas panen padi sawah sebesar 8.180 ha dan produksinya mencapai 40.696 ton, sehingga produkstifitas mencapai $50 \mathrm{kw} / \mathrm{ha}$. Kondisi luasan dan produktifitas padi sawah di Kecamatan Tenggarong Seberang ternyata mengalami peningkatan pada tahun 2013. Luas tanamnya mencapai 7.295 ha, adapun luas panenya berada di angka 8.222 ha, dengan produksi padi sawahnya mencapai 45.045,28 ton, sehingga produktivitasnya $55 \mathrm{kuintal} / \mathrm{ha}$. Dengan begitu, ini berarti 21 persen lebih produktifitas padi sawah di Kutai Kartanegara dihasilkan oleh Kecamatan Tenggarong Seberang di tahun 2013.

Angka-angka tersebut tentu merupakan angin segar bagi pertanian di Kecamatan Tenggaron Seberang. Secara luasan dan produksi padi sawah, yang merupakan komoditas pertanian utama, Kecamatan Tenggarong berada pada posisi tertinggi. Akan tetapi, lahan pertanian yang luas dengan diiringi meningkatnya produksi padi sawah ternyata tidak berkesinambungan dengan keeksistensian para petaninya. Kecamatan Tenggarong Seberang yang merupakan daerah sentra pertanian di Kabupaten Kutai Kartanegara, bahkan tertinggi baik secara luas tanam maupun poduktivitasnya, tidak dapat menghindari proses penurunan jumlah rumah tangga petani yang masif.

Berbicara mengenai pertanian maka kita tidak bisa lepaskan dari persoalan tanah. Tanah bisa dikatakan sebagai moda produksi utama dalam pertanian. Dengan sebegitu krusialnya persoalan tanah ini, sehingga keberadaannya sangat berpengaruh atas pertanian. Tanah atau lahan pertanian bukanlah objek 'mati', namun selalu berdinamika terutama dalam hal penggunaan dan penguasaannya.

Tren perubahan luas lahan pertanian di Kabupaten Kutai Kartanegara dan Kecamatan Tenggarong Seberang ternyata berbeda. Luas lahan pertanian di Kabupaten Kutai Kartanegara dalam lima tahun terakhir, tahun 2009 sampai 2013, memang cenderung mengalami peningkatan, bahkan peningkatannya cukup besar. Di tahun 2013 luas lahan pertanian di Kabupaten Kutai Kartanegara mencapai 1.307.414 ha, sedangkan di tahun 2009 hanya seluas 799.208 ha. Artinya, telah terjadi peningkatan luas lahan pertanian di Kabupaten Kutai Kartanegara dari tahun 2009 sampai tahun 2013 sebesar 63,5 persen. Untuk di Kecamatan Tenggarong Seberang sendiri, pada rentang waktu yang sama ternyata mengalami penurunan. Pada tahun 2009 tercatat luas lahan pertanian di Kecamatan Tenggarong Seberang mencapai 24.472 ha, akan tetapi di tahun 2013 luasanya hanya tinggal 11.838 ha. Berarti telah terjadi penurunan luas lahan pertanian di Kecamatan Tenggarong Seberang sebesar 51,6 persen dari tahun 2009 sampai 2013.

Jika dibandingkan dengan kecamatan-kecamatan lainnya di Kabupaten Kutai Kartanegara, luas lahan sawah yang dalam satu tahun berhasil ditanami padi, atau disebut sebagai lahan sawah fungsional, pada enam tahun terakhir, tahun 2008 sampai tahun 2013, di Kecamatan Tenggarong Seberang selalu paling luas. Apalagi, lahan sawah di Kecamatan Tenggarong Seberang sudah tidak ada lagi yang hanya ditanam satu kali dalam setahun, rata-rata sudah dua atau tiga kali tanam dalam satu tahun. Maka tidak heran 
jika Kecamatan Tenggarong Seberang dijadikan sebagai 'lumbung' padi di Kabupaten Kutai Kartanegara.

Tabel 2. Luasan Lahan Pertanian Kab. Kutai Kartanegara dan Kec. Tenggarong Seberang Tahun 2009-2013

\begin{tabular}{llll}
\hline No & Tahun & $\begin{array}{l}\text { Kab. Kutai Kar- } \\
\text { tanegara (ha) }\end{array}$ & $\begin{array}{l}\text { Kec. Tenggarong Se- } \\
\text { berang (ha) }\end{array}$ \\
\hline 1 & 2009 & 799.208 & 24.472 \\
2 & 2010 & 810.211 & 39.085 \\
3 & 2011 & 792.622 & 18.985 \\
4 & 2012 & 811.963 & 16.229 \\
5 & 2013 & 1.307 .414 & 11.838 \\
\hline
\end{tabular}

Sumber: Dinas Pertanian Kab.Kutai Kartanegara 2014, diolah.

Bisa dibilang pertanian di Kecamatan Kutai Kartanegara adalah warisan dari program transmigrasi. Saat para transmigran datang di tahun $1980 \mathrm{ke} \mathrm{Kecamatan} \mathrm{Tenggarong}$ Seberang, pertanianlah yang menjadi sumber nafkah utama bahkan satu-satunya yang dilakukan oleh masyarakat pada waktu itu. Hingga akhirnya pertanian terus bertahan sampai sekarang, walaupun tidak tidak lagi menjadi sumber nafkah utama, apalagi satu-satunya. Di lain halnya lagi, luas lahan pertanian secara signifikan terus mengalami penurunan. Penurunan luas lahan pertanian sebesar 51,6 persen selama lima tahun terakhir di Tenggarong Seberang tentu bukan merupakan angka yang kecil dan bisa diabaikan begitu saja.

Tidak bisa dinafikan jika konversi lahan pertanian yang terjadi secara besar-besaran di Tenggarong Seberang adalah karena tekanan dari hadir dan berkembangnya industri tambang. Dengan luas Kecamatan Tenggarong Seberang yang mencapai $464,25 \mathrm{~km} 2$ atau 46.425 ha, saat ini terdapat 17 perusahaan tambang yang telah mengantongi IUP operasi produksi dan 7 perusahaan yang berstatus IUP eksplorasi. Hanya dengan 17 perusahaan tambang yang telah beroperasi produksi itu ternyata telah menguasa lahan seluas 21.862,15 ha, atau setara dengan 47,1 persen dari total luas Kecamatan Tenggarong Seberang, atau sebanding dengan 26.339 buah lapangan bola (luas lapangan bola: $110 \mathrm{~m} \times 75 \mathrm{~m}$ ). Luasan area tambang ini masih memungkinkan untuk bertambah, jika ditambah dengan perusahaan tambang yang berstatus IUP eksplorasi. Total luas area tambang antara perusahaan IUP produksi dan eksplorasi adalah mencapai $27.797,15$ ha, atau 59,87 persen dari luas Tenggarong Seberang. Dengan begitu, sudah jelas jika pada faktualnya bahwa sebagian besar lahan di Tenggarong Seberang adalah lahan yang diperuntukkan untuk kegiatan tambang. Sedangkan luas lahan pertanian hanya sebesar 11.838 ha, atau setara dengan 25,5 persen dari total luas Kecamatan Tenggarong Seberang.

\section{Perubahan Struktur Agraria Desa Embalut dan Bangunrejo}

Struktur pertanahan di Desa Embalut dan Desa Bangunrejo tidak dipungkiri terkonsentrasi atas penguasaan tanah oleh perusahaan-perusahaan pertambangan batu-bara. Setidaknya ada enam perusahaan yang mengantongi IUP operasi produksi dan IUP eksplorasi di Desa Embalut dan Bangunrejo, yaitu PT. Kitadin, PT. Gerbang Daya Mandiri, PT. Bukit Baiduri Energi, PT. Kalimantan Persada Coal,
PT. La Tahzan, dan PT. Kaltim Bio Energi. Perusahaan yang telah melakukan produksinya adalah PT. Kitadin , PT. Gerbang Daya Mandiri, dan PT. Bukit Baiduri Energi. Sedangkan, PT. Kalimantan Persada Coal meskipun telah mengantongi IUP operasi produksi namun belum melakukan produksi. Adapun PT. La Tahzan, dan PT. Kaltim Bio Energi masih melakukan eksplorasi.

Saat ini perusahaan-perusahaan tambang menguasai sebagian besar lahan di Desa Embalut dan Bangunrejo. Terhitung ke enam perusahaan tambang yang berada di kedua desa itu telah mengantongi izin lokasi untuk penguasaan lahan dengan total luas 14.582 ha. Total luas lahan tambang ke enam perusahaan tambang tersebut bahkan jauh melebihi luas Desa Embalut dan Desa Bangunrejo yang hanya bertotal 5.500 ha. Padahal sebelum kehadiran perusahaanperusahaan tambang, penguasaan lahan sebagian besar diperuntukan bagi pertanian yang dikelola oleh masyarakat. Desa Embalut yang dihuni oleh Suku Kutai, lebih memanfaatkan lahan untuk pertanian berladang. Adapun masyarakat Desa Bangunrejo yang merupakan masyarakat transmigran yang dibekali oleh pemerintah tanah seluas 2 ha, lalu menggunakan lahan tersebut untuk 1 ha lahan tani sawah, 0,75 ha untuk tanah ladang dan sisanya 0,25 ha untuk rumah dan pekarangan.

Desa Bangunrejo memiliki luas wilayah sebesar $2.500 \mathrm{Ha}$ di ketinggian 15-17 meter diatas permukaan laut dengan curah hujan 2.200-2.800 mm/tahun dan suhu berkisar 2432 derajat celcius. Secara umum topografi Desa Bangunrejo di wilayah tengah dan barat adalah dataran rendah yang dipergunakan untuk pemukiman dan persawahan produktif yang menjadi andalan Desa Bangunrejo dan Kabupaten Kutai Kartanegara sebagai Lumbung Padi.

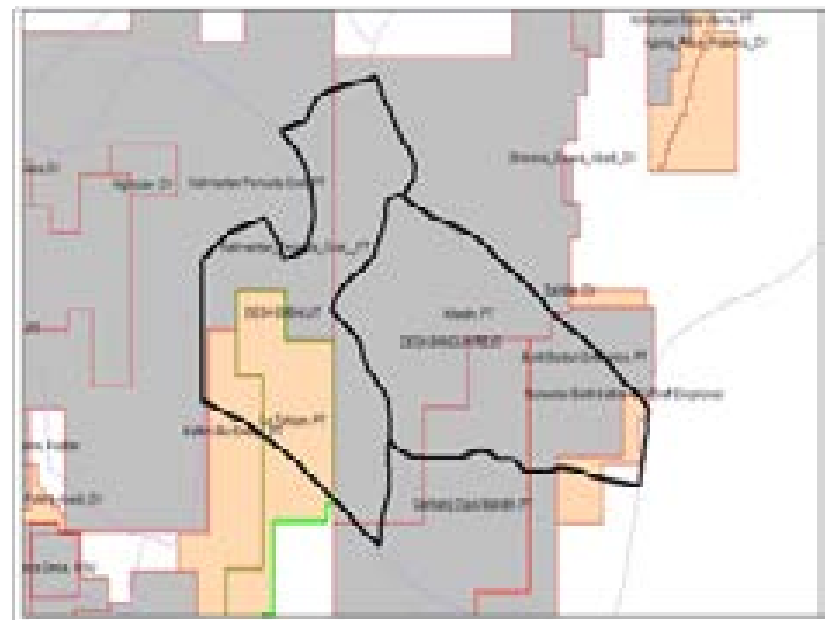

Gambar 4. Sebaran Perusahaan Tambang di Desa Embalut dan Bangunrejo

Wilayah timur dataran tinggi yang dimanfaatkan sebagai lahan perladangan tanaman palawija yang penangananya menggunakan sistem semi agrobisnis, sebagian telah dijadikan areal pertambangan batu bara oleh PT. BBE. Wilayah utara dataran tinggi yang dipergunakan untuk pemukiman dan perladangan, dan sampai saat ini sudah 80 $\%+400$ Ha telah dikuasai dan dijadikan areal pertambangan batu bara oleh PT.Kitadin, dan terdapat kolam ex galian batu bara yang telah dimanfaatkan oleh masyarakat sebagai budi daya ikan keramba. Untuk wilayah Selatan dataran 
bergelombang yang telah dikuasai oleh PT.Gerbang Daya Mandiri (GDM) untuk pertambangan batu bara berkisar + 100 ha.

Untuk Desa Embalut yang berada ditepi Sungai Mahakam memiliki luasan wilayahnya mencapai $3000 \mathrm{Ha}$, dengan ketinggian 13 meter di atas permukaan laut. Suhu rataratanya sekitar 27 derajat celicius. Berdasarkan topografinya, sebagian besar lahan Embalut merupakan perbukitan/ pegunungan dengan luas mencapai $2000 \mathrm{Ha}$ dan dataran yang mencapai sekitar $1000 \mathrm{Ha}$ (Data Monografi Desa, 2011). Areal lahan tambang (PT. Kitadin) yang berada di Desa Embalut diperkirakan hanya sekitar $200 \mathrm{Ha}$ Meskipun demikian, diduga luasan lahan yang dikuasai PT. Kitadin di Desa Embalut jauh lebih besar dari perkiraan angka tersebut.

Tidak berlebihan jika lahan pertanian di Desa Embalut dan Desa Bangunrejo kini cenderung menyempit seiring dengan perubahan pola pemanfaatan lahan, khususnya oleh sektor industri pertambangan yang sangat masif menguasai lahan. Konversi lahan pertanian ke aktivitas tambang yang tinggi menjadi faktor utama atas perubahan struktur agraria yang terjadi. Masyarakat, khususnya petani, berada dalam situasi yang mendorong mereka secara kuat untuk melepaskan tanah-tanahnya.

Tabel 3. Perubahan Penggunaan Lahan Tahun 2011

\begin{tabular}{|c|c|c|c|c|c|c|}
\hline \multirow{3}{*}{$\begin{array}{l}\mathrm{L} \text { a h a } \mathrm{n} \\
\text { Asal }\end{array}$} & \multicolumn{6}{|c|}{ Lahan Berubah Menjadi } \\
\hline & \multicolumn{2}{|c|}{$\begin{array}{l}\text { Lahan Perta- } \\
\text { nian Sawah }\end{array}$} & $\begin{array}{l}\text { Lahan } \\
\text { tanian } \\
\text { Sawah }\end{array}$ & $\begin{array}{l}\text { Per- } \\
\text { Non }\end{array}$ & \multicolumn{2}{|c|}{$\begin{array}{l}\text { Lahan Non } \\
\text { Pertanian }\end{array}$} \\
\hline & $\begin{array}{l}E \\
(\%)\end{array}$ & $\begin{array}{l}\mathrm{B} \\
(\%)\end{array}$ & $\mathrm{E}(\%)$ & $\begin{array}{l}\mathrm{B} \\
(\%)\end{array}$ & $\begin{array}{l}E \\
(\%)\end{array}$ & $\begin{array}{l}\mathrm{B} \\
(\%)\end{array}$ \\
\hline $\begin{array}{l}\mathrm{L} \text { a } \mathrm{h} \text { a } \mathrm{n} \\
\text { Pertanian } \\
\text { Sawah }\end{array}$ & - & - & 8 & - & - & 20 \\
\hline $\begin{array}{l}\mathrm{L} \text { a } \mathrm{h} \text { a } \mathrm{n} \\
\text { Pertani- } \\
\text { an Non } \\
\text { Sawah }\end{array}$ & 1 & - & - & - & 1 & - \\
\hline $\begin{array}{l}\mathrm{L} \text { a } \mathrm{h} \text { a } \mathrm{n} \\
\text { Non Per- } \\
\text { tanian }\end{array}$ & 7 & - & 1 & - & - & - \\
\hline
\end{tabular}

Keterangan:

$\begin{array}{ll}\text { E: } & \text { Desa Embalut } \\ \text { B: } & \text { Desa Bangunrejo }\end{array}$

Sumber: Podes Tahun 2011

Lahan yang sebagian besar sudah dikuasai oleh perusahaan tambang dan harga tanah yang semakin tinggi membuat petani semakin sulit untuk membeli lahan sebagai bagian dari perluasaan area garapannya. Jika dulu, sebelum tambang ada ataupun seramai sekarang, petani dapat dengan mudah untuk memperluas lahannya. Lahan yang belum digarap masih sangat luas dan juga harga tanah pada waktu itu masih murah. Sehingga, petani hanya dalam beberapa kali panen saja mampu untuk membeli lahan.

Ku ayeunamah rupina rada teubih kitu (meser taneuh), hargina kos harga perusahaan kieu. Kalo sekarang sepertinya agak susah (membeli tanah), harganya sudah seperti harga perusahaan begini. (DIN, 65)

Pada data Podes tahun 2011 menunjukan jika terjadi konversi penggunaan lahan dari lahan pertanian sawah, ke pertanian non sawah maupun ke lahan non pertanian. Di Desa Bangunrejo perubahan terjadi pada lahan pertanian sawah ke non pertanian sebesar 20 persen. Menurut penuturan dari Sekretaris Desa Bangunrejo menyebutkan jika penurunan lahan pertanian pada faktualnya lebih besar dari angka tersebut, yaitu dari $900 \mathrm{Ha}$ menjadi hanya tinggal $600 \mathrm{Ha}$ saja. Untuk di Desa Embalut perubahan penggunaan lahan relatif lebih kecil, walaupun perubahannya meliputi semua jenis lahan (lahan sawah, non sawah dan non pertanian).

\section{DINAMIKA PERTANIAN}

Pertanian diEmbalutdulu dilakukan dengan sistemberpindahpindah. Waktu tanam sampai dipanen membutuhkan waktu yang relatif panjang, yaitu mencapai lebih dari 6 bulan. Maka untuk padi yang dihasilkan pada waktu itu disebut sebagai Padi Betahun, karena dibutuhkan waktu hampir setahun untuk proses menanam padi. Pertanian menetap mulai dilakukan sekitar tahun 1990. Berpindahnya pola bertani ini sangat dipengaruhi oleh kedatangan para transmigaran yang lebih dulu menerapkan pertanian menetap. Mekanisme bertani yang baru dan lebih modern ini akhirnya mempengaruhi cara bertani orang-orang Kutai termasuk BUS (46) yang merupakan petani asli Embalut. Cara bertani yang baru ini diakuinya memang lebih baik, dari segi kualitas maupun kuantitas produksinya.

Pertanian di Embalut cenderung lebih tertingggal dibandingkan dengan di Desa Bangunrejo. Petani di Bangunrejo didominasi berasal dari Jawa, yang sudah memiliki budaya pertanian menetap lebih dulu. Akan tetapi, proses transformasi sistem bertani dari berpindah ke menetap di petani-petani Embalut tidak berjalan dengan cepat. Apalagi setelah kedatangan transmigran, pendampingan pertanian dari pemerintah cenderung lebih berfokus pada petani pengikut program transmigrasi. Sedangkan di sisi lain, masyarakat Embalut juga tidak mau untuk mengikuti program pemerintah tersebut (transmigrasi) karena merasa sudah nyaman dengan pola kehidupannya pada waktu itu. Ada anggapan pula, bahkan dikalangan masyarakat Embalut sendiri, jika orang pendatang dari Jawa memang lebih gelut dalam bertani, sedangkan Orang Kutai lebih memilih untuk tidak terlalu berusash-susah dalam bekerja.

Padahal yang terjadi adalah warga Kutai yang tidak terbiasa mengolah lahan dalam skala besar. Karena saat lahan berpindah, menggarap lahan sampai 0,5 hektar pun jarang dilakukan. Lahan-lahan yang digarap biasanya berada di tengah hutan atau bukit sehingga membuat sulit untuk dilakukan dalam cakupan yang luas, apalagi dengan peralatan tani yang masih minim dan sederhana. Pemilihan lahan yang lebih ke dalam (ke arah hutan atau bukit) karena untuk menghindari luapan air Sungai Mahakam yang sering terjadi. Hasil tani yang diperoleh akhirnya hanya bersifat subsisten, untuk memenuhi kebutuhan hidup keluarga saja. Hal inilah yang membuat pertanian di Embalut sulit untuk berkembang.

Desa Bangunrejo dinilai masih lebih berhasil pertaniannya karena sistem pertaniannya sudah terbangun cukup 
baik. Seperti sudah terbangunnya sarana pengairan, berupa selokan-selokan air, walaupun belum mencakup sepenuhnya. Jika di Embalut, petani murni hanya mengandalkan sumber air dari hujan yang turun. Selain itu petani di Embalut sering mengalami kekurangan modal untuk biaya operasional pertanian, dan tidak ada pihak yang biasa membantu untuk membiayainya. Adapun jika di Bangunrejo mekanisme bantuan pembiayaan bagi para petani itu sudah ada, yaitu yang dikenal dengan sistem 'Yarnen', bayar setelah panen. Yarnen ini bukan berasal dari pemerintah, tapi dari 'Bos-Bos' yang memberikan pinjaman modal agar petani bisa membeli pupuk dan obat-obatan. Pembayarannya dengan menjual hasil panen petani kepada bos tersebut. Setelah panen baru nanti akan dihitung total uang yang sebelumnya dipinjam. Selisih dari nilai hasil keseluruhan panen yang dikurangi dengan utang modal tani, itulah yang akan menjadi keuntungan petani. Dengan minimnya modal yang dimiliki petani membuat keberadaan sistem Yarnen ini sangat membantu, walaupun berkonsekuensi pada penjualan pasca panen yang mengharuskan mereka menjual kepada para 'Bos'. Tidak adanya dana talangan di Embalut menjadi salah satu penghambat bagi para petani. Permasalahan pertanian lainnya di Embalut adalah seringnya terjadi kelangkaan pupuk yang membuat harga sangat mahal, begitu pun dengan persediaan obat-obatan untuk pertanian.

Biaya operasional yang dikeluarkan untuk produksi sekali tanam adalah sebesar 5 juta dengan luas lahan 1,5 hektar. Dari lahan sebesar itu dihasilkan 3 ton, dengan jumlah yang diterima persatu tonnya sebesar 4 juta, sehingga total pendapatan yang diterima adalah 12 juta. Berarti keuntungan yang bisa diterima petani dalam satu tanam adalah sekitar 6 juta. Dengan masa tanam padi sawah yang biasanya memakan waktu selama tiga bulan, bisa dihitung jika rata-rata pendapatan petani setiap bulannya dengan lahan seluas 1,5 hektar adalah hanya sekitar 2 juta per bulan. Pendapatan petani ini bisa berkurang lagi jika luas lahan yang digarap lebih kecil.

Biaya produksi yang tinggi sedangkan selisih pendapatan yang diterima tidak begitu besar membuat sektor pertanian dianggap kurang begitu dapat memberikan jaminan hidup yang lebih. Jika dibandingkan pertambangan, pertanian jelas kalah 'pamor' atau dengan sektor-sektor usaha non pertanian lainnya yang dianggap lebih menguntungkan, memberikan kepastian dan relatif cepat terasa hasilnya.

Tani sawah memang masih menjadi komoditas pertanian utama di Bangunrejo dan Embalut, walaupun dinilai keuntungannya kurang menggiurkan. Padahal pekerjaan di pertanian sebenarnya sangat menjanjikan. Apalagi dipertanian holtikultura. Semisal apa yang dialami oleh seorang petani, SUD (51), dengan menanam cabe yang hanya seluas $1 / 4$ hektar, ternyata ia mampu menghasilkan 1,5 ton. Harga jual cabe pada waktu itu sebesar 20.000 rupiah, sehingga hasil yang ia didapatkan mencapai 30 juta rupiah. Keuntungan yang didapatkan dari menanam cabe memang sangat besar, apalagi modal yang dikeluarkan untuk menanan $1 / 4$ hektar cabe hanya sebesar 7 juta. Belum lagi, waktu tanam tanaman hotikultura relatif lebih cepat. Mengolah lahan cabe sampai penanaman hanya memakan waktu satu bulan, ditambah masa menunggu panen yang mencapai 70 hari. Sedangkan waktu menanam padi dalam setahun hanya bisa dilakukan dua kali.

Keberadaan tambang juga mempengaruhi produksi pertanian. Jika dulu dalam dalam 1 hektar mampu menghasilkan 70 karung gabah kering geling dengan penggunaan pupuk 2,5 kwintal, namun untuk saat ini paling maksimal hanya 60 karung gabah kering giling dengan penggunaan pukuk mencapai 3,5 kwintal. Berdasarkan data sensus pertanian 2013, dari $2400 \mathrm{kk}$ penduduk Desa Bangunrejo, hanya 700 kk yang merupakan keluarga petani. Sedangkan di Desa Embalut, di tahun 2011, jumlah rumah petani hanya ada sebanyak $95 \mathrm{kk}$, dan keluarga yang anggotanya menjadi buruh tani ada $30 \mathrm{kk}$. Rata-rata luas penguasaan lahan oleh petani saat ini semakin menyempit.

Di Desa Embalut, berdasarkan data pada tiga kelompok tani, Berkat Etam, Karya Baru dan Loa Manik, memperlihatkan jika rata-rata luas penguasaan lahan petani hanya seluas 0,22 Ha. Menyempitnya luas lahan petani tentu mengakibatkan pada skala produksi pertanian para petani yang tidak tinggi. Sehingga hasil tani akhirnya hanya memenuhi untuk kebutuhan konsumsi keluarga sendiri, karena skala usaha yang tidak ekonomis.

\section{PERKEMBANGAN EKONOMI DESA}

\section{Ekonomi di Desa Bagun Rejo: Transformasi Desa Transmigrasi menjadi Desa Tambang}

Desa Bangunrejo adalah desa transmigrasi, maka desa ini adalah desa pertanian. Dalam Garis Besar Haluan Negara tahun 1983 telah diterangkan jika: Transmigrasi ditujukan untuk meningkatkan penyebaran penduduk dan tenaga kerja serta pembukaan dan pengembangan daerah produksi baru, terutama daerah pertanian, dalam rangka pembangunan daerah, khususnya di luar Jawa dan Bali, yang dapat menjamin peningkatan taraf hidup para transmigran dan masyarakat di sekitarnya. Pelaksanaan transmigrasi sekaligus merupakan usaha penataan kembali penggunaan, penguasaan dan pemilikan tanah baik di daerah asal maupun di daerah tujuan (Bappenas, 1983)

Di tahun 1980, di awal-awal transmigrasi, komoditas pertanian didominasi dengan pertanian padi-sawah dengan sedikit tanaman palawija. Karena semua warga Bangunrejo adalah warga transmigran, maka hampir semua mata pencahariannya adalah sebagai petani. Walaupun ditunjang penuh oleh pemerintah dalam hal rumah, tanah dan sarana produksi pertaniannya, namun produksi pertaniannya masih cukup rendah pada waktu itu. Hasil pertanian masih diutamakan untuk memenuhi konsumsi rumah tangga sendiri, jika ada sisa baru dijual, biasanya dijual ke kota Samarinda. Kondisi alam dan sarana prasarana yang masih belum memadai, membuat mereka terpaksa hidup dalam masa penuh keprihatinan. Saat itu belum ada listrik, penerangan di malam hari biasanya menggunakan lampu minyak tempel, atau petromak.

Awal-awal kedatangan para transmigran ke Bangunrejo, tahun 1980 sampai 1982, sebenarnya masa dimana masyarakat berantusiasme tinggi terhadap program transmigrasi dan harapan membangun penghidupan yang lebih baik. Akan tetapi, berbarengan dengan itu juga, beragam kesulitan banyak dialami oleh para transmigran. Pengalaman yang dialami DID (65), transmigran asal Cianjur, Jawa Barat misalnya, di awal kedatangannya ke Bangunrejo menurutnya adalah masa-masa terberat. Wilayah Bangunrejo waktu itu hampir semua hutan, lahan masih berbelukar-belukar, sepi, panas, serta kondisi tanah dan alam yang cukup berbeda dengan di Jawa Barat. Proses 
adaptasipun tidak bisa dilakukan dengan cepat dan terasa begitu menyulitkan.

Memasuki tahun 1983, terjadi anomali atas siklus alam yang berdampak cukup masif. Kemarau panjang menimpa Kalimantan. Desa-desa di Tenggarong Seberang pun tak luput dari fenomena alam itu. Hampir lebih dari satu tahun, sampai tahun 1984, kemarau panjang berlangsung. Hujan tidak turun sama sekali. Kemarau yang cukup parah ini menyebabkan ratusan hektar hutan terbakar dan lahanlahan pertanian kering kerontang. Kekeringan kritis terjadi yang juga mengakibatkan kritisnya kehidupan masyarakat akibat sumber penghidupannya, yaitu pertanian mengalami paceklik. Lahan sulit untuk digarap, karena air tidak tersedia, petani pun tidak bisa menanam sama sekali. Aktivitas pertanian bisa dikatakan lumpuh total.

Dalam kondisi ini masyarakat pun terpaksa mulai mencari jalan keluar atas kesulitannya itu, terutama untuk bisa tetap bertahan hidup. Sehingga banyak para transmigran yang memilih untuk merantau ke daerah lain, ada yang bekerja sebagai buruh perkebunan, atau bekerja di luar pertanian seperti sebagai buruh bangunan, atau banyak yang akhirnya memutuskan untuk pulang kampung ke daerah asal. DID (65) adalah salah satu masyarakat yang merasa tidak kuat untuk menjalani kehidupannya di Bangunrejo saat itu, dan akhirnya memilih pulang ke kampung halamannya di Cianjur, Jawa Barat pada tahun 1986, bersama istri dan anaknya.

Ia kembali ke Cianjur setelah sebelumnya menjual tanah beserta rumah transmigrasinya senilai tiga juta rupiah, yang sebenarnya merupakan milik pemerintah dan tidak bisa diperjualbelikan. Akan tetapi dengan kondisi yang tertekan ia terpaksa menjualnya untuk biaya pulang kampong. Namun, hanya sekitar satu tahun ia bertahan di daerah asalnya. Ternyata kondisi di Cianjur pada waktu itu menurutnya tidak lebih baik dari Kalimantan dan bahkan tidak memberikan harapan kedepannya. Tahun 1987 pun ia kembali ke Kalimantan, tepatnya ke Muara Tewe, Kalimantan Tengah. Ia bisa ke sana juga karena ikut program transmigrasi, dan kembali bekerja sebagai petani. Namun lagi-lagi ia tidak kerasan. Jarak yang jauh dari kota mencapai $40 \mathrm{~km}$, dan kontur wilayahnya yang berbukit-bukit sehingga agak menyulitkan untuk kegiatan pertanian. Dari itulah akhirnya ia pun memutuskan pergi. Seoalah seperti pepatah 'jika jodoh tak akan pergi kemana', di tahun 1990, DID (65) kembali datang ke Bangunrejo. Menurutnya, dari beberapa tempat yang telah ia coba tinggali, termasuk Cianjur daerah asalnya, Desa Bangunrejo adalah tempat yang paling menjanjikan untuk membangun kehidupan. Walaupun untuk periode peruntungan kedua di Bangunrejo ini, ia harus kembali memulai dari nol. Bahkan untuk tempat tinggal hidup pun ia terpaksa menumpang di rumah mertuanya yang kebetulan juga adalah seorang transmigran tahun 1980, yang hanya saja jika mertuanya itu tetap bertahan saat masa-masa kritis di tahun 1983.

Pada tahun 1983 juga berbarengan dengan beroperasinya perusahaan tambang yaitu PT. Kitadin. Beroperasiya perusahaan tambang ternyata tidak membutuhkan waktu lama untuk dapat berdampak nyata pada keadaan desa, tidak hanya dari segi fisik, tapi termasuk ekonomi. Pekerja tambang sudah barang tentu menjadi pekerjaan yang muncul karena memang dibuka oleh perusahaan. Namun selain itu, usaha perdagangan juga mulai berkembang di masyarakat Bangunrejo. Walaupun demikian, sektor pertanian tetap menjadi sumber pencaharian mayoritas masyarakat.

Dengan hadirnya perusahaan tambang turut membuka lebih banyak akses-akses jalan, dam masuknya listrik ke desa. Meskipun kehadiran jalan dan listrik tersebut lebih diutamakan untuk aktivitas perusahaan. Tidak bisa dipungkiri kehadiran perusahaan tambang telah membuat desa lebih hidup. Beroperasinya PT.Kitadin yang merupakan sebuah perusahaan tambang, telah membuat corak Desa Bangunrejo, yang sebelumnya hanya desa transmigran 'biasa', menjadi lebih yang ramai dengan pekerja-pekerja tambang dan deru-deru galiannya.

Menurut AY, salah satu aparat desa, hanya butuh 4 tahun semenjak berproduksinya penggalian tambang, kira-kira di tahun 1987 sektor pertambangan sudah mulai mendominasi sumber nafkah di masyarakat. Hal ini didorong karena persyaratan untuk bekerja di tambang sangat mudah, hanya bermodal Kartu Tanda Penduduk (KTP), dan biasanya berjenis kelamin laki-laki, lalu siapapun bisa bekerja di tambang.

Geliat ekonomi di Bangunrejo pun terus mengalami perkembangan. Pada tahun 1994 diadakan Bulan Bakti LKMD (Lembaga Ketahanan Masyarakat Desa) yang kegiatannya yaitu mengaspal jalan utama di Bangunrejo. Dengan kondisi jalan yang telah beraspal membuat mobilitas masyarakat semakin tinggi. Hasil-hasil pertanian dapat dengan mudah dipasarkan. Hal ini tentunya membuat pertanian semakin berkembang. Selain itu pun, di tahun ini mulai muncul industri-industri rumah tangga, seperti industri pabrik genteng, dan batu bata.

Pada penutupan operasi tambang dalam tahun 2007 tidak kurang sebanyak 3000 orang pekerja diputus hubungan kerja (PHK) oleh perusahaan, dengan 1500 diantaranya adalah warga Desa Bangunrejo. Untuk mengantisipasi gejolak besar dari masyarakat akibat PHK besar-besaran tersebut, pihak perusahaan telah melakukan sosialisasi atas kebijakannya itu. Sosialisasi penutupan tambang dalam berlangsung selama hampir dilakukan satu tahun, sehingga secara umum warga tidak merasa kaget. Terlebih lagi adalah sosialisasi terkait besaran kompensasi yang akan diterima oleh pekerja. Tunjangan akhir pekerja diberikan dengan perhitungan, gaji terakhir dikali masa kerja lalu dikali tiga. Bagi masyarakat yang bekerja sejak dibukanya PT. Kitadin, tahun 1983, konpensasi yang mereka dapatkan bisa mencapai ratusan juta rupiah. Bahkan, untuk beberapa posisi tinggi, besaran kompensasinya bisa mencapai 500 juta. Sebenarnya, setiap pekerja diberikan opsi lain jika masih ingin bekerja, yaitu mereka dipindah kerja ke perusahaan tambang lain. Hanya memang, sebagian besar menolak pilihan dipindah kerja.

Besarnya nilai kompensasi yang akan mereka terima adalah sesuatu hal yang sulit ditampik oleh masyarakat. Kesempatan untuk bisa mendapatkan sejumlah uang dalam nominal yang besar adalah hal yang langka mereka alami. Bayang-bayang untuk bisa memperoleh apa yang selama ini mereka inginkan, seperti membeli rumah, membeli mobil, beli tanah, dan naik haji adalah beberapa hal yang sangat mempengaruhi keputusan pekerja. Walaupun juga, banyak pekerja yang memang sudah merasa lelah bekerja di tambang, apalagi yang sudah dari awal sejak berdirinya PT. Kitadin, pada 30 tahun lalu. Selain itu, masyarakat menilai jika pemberhentian dengan kompensasi yang diberikan 
adalah hal yang sangat menguntungkan. Jika pun mereka ingin kembali bekerja di tambang, saat ini sudah banyak dibuka perusahaan-perusahaan tambang di Kecamatan Tenggarong Seberang.

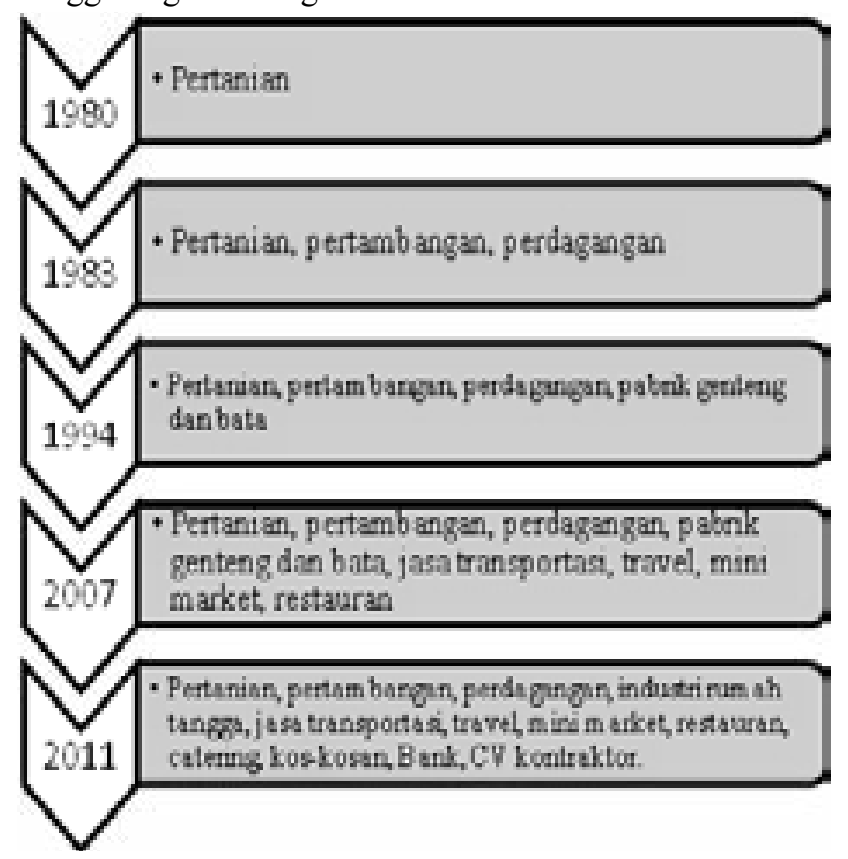

Gambar 5. Dinamika Sumber Nafkah Masyarakat Desa Bangunrejo

Dengan PHK ini banyak masyarakat yang mendapatkan dana 'segar' dari kompensasi pemberhentian tersebut. Dengan modal yang didapat itu, kemudian bermunculanlah usaha-usaha baru di tengah masyarakat seperti, jasa transportasi, jasa travel, mini market dan rumah makan. Daya beli masyarakat yang sudah semakin tinggi membuat usaha-usaha baru menjadi lebih diterima secara pasar.

Proses pembangunan di Bangunrejo kembali menjadi pemantik munculnya usaha-usaha ekonomi baru. Tahun 2011, Desa Bangunrejo menerima program semenisasi jalan desa sepanjang 8 kilometer. Semenjak itu, usaha-usaha yang sebelumnya belum pernah ada, yaitu CV kontraktor, catering makanan, kos-kosan, Bank, BPR, BPD, warnet semakin meramaikan perekonomian di Desa Bangunrejo. Proses pembangunan di desa ternyata cenderung selalu berdampak terhadap perekonomian desa, walaupun usahausaha yang berkembang adalah kebanyakan usaha nonpertanian.

\section{Ekonomi Desa Embalut: Transformasi Desa Ladang Berpindah, Pembalakan Kayu, dan menjadi Desa Tambang}

Masyarakat Suku Kutai yang merupakan penduduk asli Desa Embalut adalah masyarakat dengan karakter pertanian. Pada mulanya orang kutai hidup dengan cara pertanian berpindah dan mencari ikan di sungai. Dengan basis penghidupan seperti itu, orang Kutai dulu terbagi dalam dua, ada yang tinggal di dalam kebun dan di sepanjang sisi Sungai Mahakam. Untuk yang tinggal di kebun, mereka melakukan aktivitas pertanian berpindah, sedangkan yang di tepi sungai mereka menangkap ikan.

Aktivitas kerja menanam padi ladang dan menangkap ikan yang dilakukan oleh masyarakat Kutai masih bersifat untuk memenuhi kebutuhan hidup keluarganya saja. Luas lahan yang terbatas membuat orientasi produksi belum sampai untuk memenuhi kebutuhan pasar, profit oriented. Sistem pertanian nomaden ini berlangsung cukup lama, bahkan setelah kedatangan para transmigran di tahun 1980 yang sudah menerapkan pertanian menetap ladang-sawah. Teknologi sistem pertanian yang masih sederhana membuat hasil produksi petani Embalut jauh berbeda dengan petani transmigran. Keadaan yang menjadikan petani Embalut cenderung lebih 'di bawah' petani Desa Bangunrejo. Baru pada tahun 1990 pertanian menetap mulai dilakukan oleh petani-petani Embalut. Berarti dibutuhkan waktu kira-kira 10 tahun untuk petani Embalut menerima dan menyesuaikan sistem pertanian baru yang dibawa oleh petani transmigran.

Desa Embalut yang berada di pinggir Sungai Mahakam membuat arus transportasi via sungai cukup ramai. Apalagi sejak tahun 1970 usaha kayu mulai merambah di Embalut dengan Sungai Mahakam yang dijadikan sebagai jalur pengangkutan utamanya. Melalui Sungai Mahakam pengangkutan kayu-kayu gelondongan lebih mudah untuk dibawa. Dengan kapal atau bahkan hanya diikatkan, kayukayunya bisa langsung dialirkan begitu saja di sungai menuju hilir. Untuk kapal angkut kayu biasanya kapasitasnya bisa mencapai 100 kubik untuk sekali angkut. Adapun harga harga jasa angkut kayu dengan kapal yaitu 100 ribu/kubik. Jadi untuk sekali jalan (ret) dengan pengangkutan kayu yang full (100 kubik) harga yang dikenakan mencapai 10 juta rupiah.

Usaha kayu di Embalut memang sempat menjadi booming di masyarakat, tak lain karena perputaran uang di usaha ini yang cepat dan tinggi. Untuk upah pengangkut kayu pada tahun 1980an dihargai 7500/kubik, dengan rata-rata sekitar tiga kubik perhari. Jadi setiap hari buruh pengangkut kayu pendapatannya bisa mengantongi sebesar 22.500 rupiah. Pendapatan sebesar itu, pada waktu itu dinilai sangat besar, bahkan jauh lebih besar bila dibandingkan dengan kerja sebagai petani maupun di perusahaan pertambangan.

Maka tidak aneh jika Orang Kutai mulanya jarang ada yang mau ikut bekerja di perusahaan tambang. Dengan upah yang lebih rendah dan waktu kerja yang sudah tetap membuat kehadiran tambang tidak begitu disambut gembira oleh masyarakat Embalut. Perhatian masyarakat seolah tercurah penuh pada usaha kayu. Keberlimpahannya kayu Ulin di alam, dan permintaan yang tidak hentinya dengan harga tinggi membuat usaha ini primadona bagi sebagian besar masyarakat Embalut. Walaupun begitu, sebagian besar pula orang yang terlibat dalam bisnis kayu ini adalah pengangkut dari kayu-kayu illegal loging.

\section{"Di kayu, hari ini kerja hari ini dapat duit. Kalo di tambang, hari ini kerja baru setelah 1 bulan dapat duitnya" (SAB, 46)}

Pembalakan kayu liar terjadi dengan begitu masif. Selain itu pun praktek-praktek pungutan liar begitu marak yang membuat biaya operasional usaha ini begitu tinggi. Seperti apa yang dialami oleh SUG (54) yang pernah bekerja sebagai kepala kerja buruh angkut kayu, lalu pernah memiliki usaha penebangan kayu dengan 5 alat Chingsonya (mesin pemotong kayu) yang dibelinya dengan harga 275 ribu per buah, dan kemudian memiliki kapal angkut kayu sendiri. Menurutnya, usaha kayu memang perputaran uangnya sangat besar, namun biaya operasionalnya pun 
tinggi. Diceritakan olehnya jika untuk mampu memiliki dan menjalankan usaha kapal angkut kayu mengeluarkan biaya yang tidak sedikit. Biaya untuk membuat kapal waktu itu sebesar 100 juta rupiah. Uang itu ia dapatkan dari pinjaman di bank. Kapasitas kapal yang ia buat mampu mengangkut sampai 100 kubik kayu. Dengan kapal ini, setiap pengangkutan kayu yang dilakukan dikenakan tarif sebesar $100 \mathrm{ribu} / \mathrm{kubik}$. Jadi sekali jalan (ret), yang biasanya full (100 kubik), mencapai 10 juta. Di sisi lain biaya operasional yang dikeluarkan seperti, gaji karyawan yang berjumlah 4 orang, dengan $400 \mathrm{ribu} /$ orang/ ret. Selain itu ada pula biaya akomodasi lainnya (makan karyawan dan bensin) yang mencapai 1,5 juta. Dan biaya yang paling tinggi adalah pungutan-pungutan 'liar' yang harus ia keluarkan. Biaya ini biasanya dikeluarkan pada petugaspetugas yang meminta 'jatah' saat dalam perjalanan kapal kayu. Besar bayaran yang harus ia keluarkan bisa mencapai 5 sampai 7 juta rupiah sekali perjalanan.

Keberlangsungan usaha perkayuan di Embalut cukup lama. Namun dengan gaya bisnis ini yang begitu eksploitatif, tanpa memperhatikan proses regenerasi kayu-kayu yang menjadi komponen utama bisnis ini, akhirnya perlahan-lahan usaha kayu ini pun menyurut. Puncaknya semenjak tahun 2005, setelah diberlakukannya moratorium hutan oleh Presiden Susilo Bambang Yudhoyono, dan pengawasan dari pihak kepolisian yang semakin ketat, sudah hampir tidak lagi ditemukan masyarakat yang berusaha di bisnis kayu.

Dengan usaha kayu yang meredup masyarakat Embalut pun mulai membuka diri dengan aktivitas tambang. Namun, sektor pertanian yang merupakan basis awal pencahariaan masyarakat Embalut ternyata tidak lagi diminati. Bekerja di tambang dinilai lebih cocok dengan kondisi kehidupan saat ini. Usaha kayu yang sempat digeluti oleh sebagian besar masyarakat dalam waktu yang cukup lama dengan karakter sistem usahanya yang bersifat praktis, cepat dan melibatkan nominal uang yang relatif tinggi akhirnya membentuk masyarakat yang memiliki karakter yang serupa. Masyarakat menjadi lebih senang pekerjaan yang bersifat instan dengan sisi ekonomis yang lebih menguntungkan. Lalu pertanian dianggap tidak masuk dalam kualifikasi tersebut.

Berbarengan dengan sudah semakin terbukanya masyarakat Embalut, usaha-usaha perdagangan dan penyedia jasa pun mulai semakin berkembang. SAB (46) salah satu warga Embalut yang dulu pernah bekerja di tambang dan juga berbisnis kayu, sejak tahun 2007 membuka warung kelontongan dan bengkel di rumahnya. Sebenarnya SAB (46) ini adalah seorang petani, dari sebelum bekerja di PT. Kitadin. Namun, pertanian yang dilakukannya adalah hanya sekedar pertanian sambilan. Tapi karena bersifat sambilan tersebut, ia tetap bertani saat ia bekerja di tambang, maupun saat berusaha kayu dan bertahan sampai saat ini. Akan tetapi, karena sambilan itu pula, pertanian yang digarapnya hanya sekedar untuk memenuhi kebutuhan keluarga saja. Ia merasa pertanian di Embalut jika dijadikan sebagai pencaharian utama atau satu-satunya tidak dapat diandalkan. Persoalan tekhnis, terutama terkait pengaturan air adalah kendala utama pertanian di Embalut menurutnya. Saat peneliti melakukan wawancara di rumahnya, disamping rumahnya adalah lahan miliknya yang kebetulan memang sedang tergenang air, sehingga tidak bisa diolah. Tergenang lahannya tersebut, menurutnya juga semakin diperparah setelah jalan Kecamatan yang tepat di depan rumahnya itu di beton. Akibat betonisasi jalan tersebut, jika telah turun hujan aliran air jadi tidak lancar, tertahan oleh jalan, yang seharusnya mengalir ke Sungai Mahakam, yang hanya berjarak sekitar 50 meter.

Pada saat ini usaha-usaha sudah semakin berkembang di Embalut, walaupun memang tidak sebanyak dan seberagam dengan di Desa Bangunrejo. Hal ini bisa dikarenakan oleh letak geografis Desa Embalut yang lebih menjorok ke arah Sungai Mahakam dan harus melewati sekitar 2 kilometer wilayah tambang, sedangkan Desa Bangunrejo berada dijalur jalan utama, yaitu Jalan Provinsi sehingga dalam segi akses lebih mudah.

Saatinimasihlebih dari 50\% warga Embalutmenggantungkan kehidupannya pada keberadaan perusahaan tambang. Angka ini tentu masih besar, apalagi dengan waktu operasi PT. Kitadin yang tidak dapat dipungkiri merupakan perusahaan besar dan utama di Embalut, yang hanya tinggal beberapa tahun lagi izin operasinya dan sudah tidak bisa diperpanjang karena sudah mau 40 tahun. Banyak dari masyarakat yang kemudian memilih kerja di perusahaan tambang lain yang memiliki waktu operasi yang masih panjang. Pilihan itu memang cukup besar, memperhatikan bersebarannya perusahaan tambang di sekitar Tenggarong Seberang. Akan tetapi tetap tidak bisa ditampik, jika kehadiran PT. Kitadin yang sudah begitu melekat dengan Desa Embalut dan Bangunrejo, sehingga penutupan perusahaan pasti akan menimbulkan pengaruh.

Walaupun memang sudah ada beberapa masyarakat yang sadar, dan akhirnya membuka usaha lain, diluar tambang. Jasa dan perdagangan adalah usaha yang banyak dipilih. Namun menariknya, beberapa usaha tersebut merupakan usaha yang berbasis pada pemanfaatan sumberdaya alam yang ada. Ada yang berusaha pengerukan pasir di Sungai Mahakam, terlihat juga usaha-usaha keramba ikan yang dilakukan oleh masyarakat di Sepanjang Sungai Mahakam, serta pertanian dan peternakan yang semakin digalakan oleh pemerintah daerah.

Berkembangnya ekonomi ini sebenarnya adalah seiring dengan semakin meningkatnya jumlah penduduk Desa Embalut, namun di sisi lain semakin berkurangnya produktivitas PT. Kitadin, yang akhirnya berimplikasi pada pengurangan jumlah karyawan. Masyarakat diperhadapkan pada keharusan untuk mempunyai pekerjaan atau usaha di luar tambang. Di lain hal, sementara pekerjaan di sektor non pertanian yang membutuhkan skill dan pendidikan memadai semakin sulit di akses, maka terjadilah fenomena "arus balik" (Kinseng et all, 2013). Sektor pertanian dijadikan sebagai alternatif dan penyelesaian atas keterhimpitan ekonomi yang dihadapi masyarakat.

Hal ini sebenarnya juga berkaitan dengan ketersediaan lahan bekas tambang PT. Kitadin yang lumayan luas. Masyarakat memanfaatkan lahan tersebut untuk bertani ataupun sebagai areal peternakan. Masyarakat yang menggarap lahan perusahaan ini biasanya telah mempunyai hubungan dekat dengan pihak internal perusahaan, baik mantan pekerja tambang di Kitadin ataupun aparat pemerintah desa. Dengan begitu proses perijinan untuk peminjaman lahan perusahaan lebih mudah. Menariknya, banyak para penggarap lahan perusahaan yang menggarap bekas lahannya sendiri yang telah dijual ke perusahaan.

Pemanfaatan dan pengelolaan lahan terlantar (belum ditambang) PT. Kitadin biasanya dipergunakan untuk 
kegiatan pertanian sawah tadah hujan. Sementara, masyarakat setempat juga memanfaatkan lahan-lahan ex. tambang atau ex. open pitmining dengan menjadikan area tersebut sebagai lahan garapan untuk pertanian, peternakan dan usaha perikanan (budidayaikan keramba apung). Beberapa petani berhasil dalam memanfaatkan dan mengolah lahan perusahaan tersebut, salah satunya BAY (52) yang meminjam lahan perusahaan dengan luasan yang tidak tanggung-tanggung sebesar $15 \mathrm{Ha}$. Penghasilan yang mampu diraup oleh BAY (53) setiap bulannya ratarata mencapai 10 juta rupiah. Kesuksesan BAY (53) yang tergabung dalam kelompok tani Mandiri Bersama dalam mengelola dan memanfaatkan lahan perusahaan ini menjadikannya sebagai role model oleh perusahaan, jika lahan bekas tambang yang digarap oleh masyarakat bisa sukses.

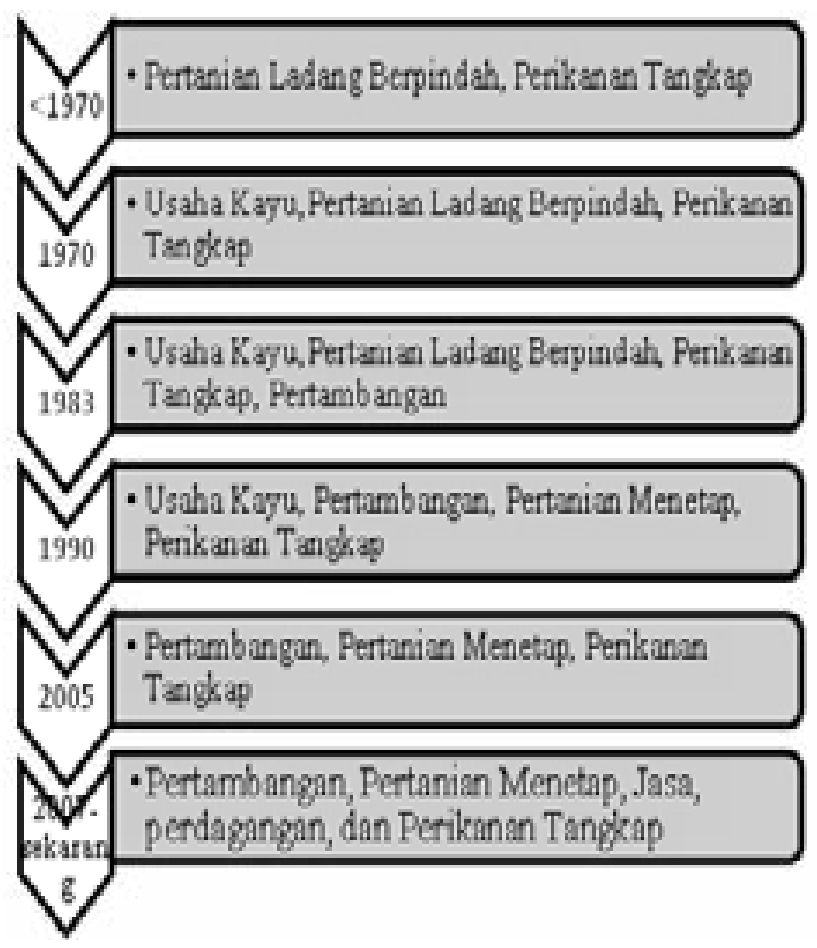

Gambar 6. Dinamika Sumber Nafkah Masyarakat Desa Embalut

Dari keberhasilan sejumlah petani menggarap lahan terlantar PT. Kitadin bisa dijadikan sebagai titik cerah pertanian di Embalut. Hal ini tentu membuat semacam perubahan cara pandang beberapa pihak terhadap kondisi pertanian di area pertambangan. Anggapan selama ini jika lahan bekas tambang tidak bisa dijadikan untuk lahan pertanian ternyata tidak sepenuhnya benar demikian. Tanda sudah mulai mendapatkannya perhatian masyarakat pertanian sekitar tambang, khususnya di Embalut adalah dengan kedatangan Gubernur Kalmantan Timur, Awang Faorek ke kelompok tani Mandiri Bersama yang disambut meriah oleh petani-petani lainnya di sekitar Desa Embalut dan juga oleh PT. Kitadin. Dengan sudah adanya success story ini diharapkan akan mendorong PT. Kitadin untuk melakukan upaya-upaya yang lebih serius dalam membina kelompok-kelompok petani penggarap lahan perusahaan tersebut. Meskipun saja hal ini tidak bisa dilepaskan dari kepentingan PT. Kitadin sendiri untuk "mencitrakan" dirinya, sebagai perusahaan tambang yang peduli terhadap kesejahteraan masyarakat setempat dan berpihak pada lingkungan.

\section{SIMPULAN}

Berdasarkan penelitian ini disimpulkan: (1) Industrialisasi pertambangan telah merubah struktur pertanahan di Desa Embalut dan Desa Bangunrejo dimana penguasaan tanah di kedua desa tersebut telah terkonsentrasi pada perusahaanperusahaan pertambangan batubara; (2) Industrialisasi pertambangan semakin mendorong masyarakat untuk bekerja atau bermatapencaharian di luar pertanian (deagrarianisasi).

\section{SARAN}

1. Pemerintah daerah Provinsi Kalimantan Timur dan Kabupaten Kutai Kartanegara hendaknya meninjau kembali Rencana Tata Ruang Wilayah daerahnya, terutama terkait dengan penguasaan lahan pertambangan yang sangat masif perkembangannya sehingga mendesak keberadaan lahan pertanian.

2. Pemerintah daerah, khususnya dinas pertanian, hendaknya melakukan pendampingan dan bantuanbantuan teknis maupun non teknis kepada para petani dengan lebih terencana dan komprehensif.

3. Pemerintah desa hendaknya untuk membuat master plan desa yang melibatkan partisipasi masyarakat terutama terkait dengan kondisi desa pasca tambang

4. Perusahaan pertambangan hendaknya melakukan pengembangan masyarakat dan rencana pasca tambang yang tidak hanya memperhatikan aspek lingkungan namun juga aspek sosial, ekonomi dan budaya masayarakat.

\section{DAFTAR PUSTAKA}

Agusta, Ivanovich. 1997. Respons Komunitas Terhadap Industrialisasi Desa(Studi Kasus Desa Kedungdowo, Kecamatan Kaliwungu, Kabupaten Kudus, Provinsi Jawa Tengah). [tesis]. Bogor: Sekolah Pascasarjana IPB.

[BPS Kutai Kartanegara]. 2014. Kabupaten Kutai Kartanegara dalam Angka Tahun 2014. [internet]. Dunduh pada 4 Januari 2014. Dapat diunduh dari. http://Kutai Kartanegarakab.bps.go.id/

Bryceson, Deborah Fahy. 2002. The Sramble in Africa: Reorienting Rural Livelihoods. [Jurnal]. World Development Vol.30, No.5, pp. 725-739, 2002: Great Britain.

Erman, Erwiza. 2007. Rethinking Legal and Illegal Economy: A Case Study of Tin Mining in Bangka Island. [tidak diketahui]

Kemp, Deanna. 2009. Mining and Community Development: Problems and Possibilities of LocalLevel Practice. Community Development Journal Advance, Access Published, February 24, 2009: Oxford University Press.

Kinseng, Rilus A et al. 2013. Pertambangan dan 
Transformasi Desa. Bogor: IPB

[Kompas.com]. 2013. Tambang Merajalela, 10 Kecamatan di Kutai Kartanegara Terancam Bencana. [Internet]. Diunduh pada 4 Januari 2014. Dapat diunduh dari: http://regional.kompas.com/ $\mathrm{read} / 2013 / 11 / 07 / 1917124 /$ Tambang.Merajalela.10. Kecamatan.di.Kutai Kartanegara.Terancam. Bencana.

O'Faircheallaigh, Cairan. 2012. Extractive Industries and Indigenous Peoples: A Changing Dynamic? Journal of Rural Studies 30 (2013): 20-30. Elsevier Ltd.

Redclift, Michael. Development and the Environmental Crisis: Red or Green Alternatives?. London dan New York: Methuen. 